\title{
Analisa Perilaku Balok Beton Bertulang dengan Menggunakan Simulasi VecTor2
}

\author{
Sudarno TAMPUBOLON ${ }^{1}$ \\ ${ }^{1}$ Jurusan Teknik Sipil, Fakultas Teknik, Universitas Kristen Indonesia, \\ email : darno_tampubolon@yahoo.com
}

\section{Sejarah artikel}

Diserahkan:

Dalam bentuk revisi: 21 September 2020
Diterima: $\quad 28$ September 2020

Tersedia online: $\quad 30$ September 2020

\begin{abstract}
Structural failure can adversely affect the comfort level of the structure. It is essential to understand the structural behavior due to the applied load because it can help predict the under-construction structure's structural strength and comfort. One way to determine and predict both the strength and comfort of a structure in response to the applied load is by conducting laboratory tests and simulations. The VecTor 2 simulation was employed to predict the shear force, crack, and displacement of the reinforced concrete beam when given displacement loads. The strength and the hysteretic response of the reinforcement concrete beam types $A 1$ and $A 2$ were considerably influenced by bonds stress-slip, which is why this study also examines the influence of bond stress-slip on the strength of the concrete beam. Results from VecTor 2 simulation using the bond stress-slip effect were compared to the result of the experimental laboratory test to assess the simulation test's accuracy. In this research, bond-slip value of 0.08 was found, and the ratio value for all peak loads was recorded between 1.05 and 1.06.
\end{abstract}

Keywords: reinforced concrete of beam, experiment test, crack, bond stress-slip effect, VecTor2 simulation

\begin{abstract}
Abstrak
Kegagalan struktur dapat berdampak buruk pada tingkat kenyamanan struktur. Penting untuk mengetahui perilaku struktur akibat beban yang ditopang karena dapat membantu memprediksi kekuatan struktur dan kenyamanan struktur yang sedang dikerjakan. Salah satu cara untuk mengetahui dan memprediksi kekuatan dan kenyamanan struktur akibat beban yang diterima adalah dengan melakukan pengujian laboratorium dan simulasi. Simulasi VecTor2 digunakan untuk memprediksi gaya geser, retak, dan displacement yang terjasi pada balok beton bertulang pada saat diberikan beban perpindahan. Tegangan ikatan (bond-slip) memberikan pengaruh yang besar terhadap kekuatan dan respon histeris pada balok tipe A1 dan A2. Oleh karena itu, penelitian ini juga mengkaji pengaruh bond-slip terhadap kekuatan balok beton bertulang. Seluruh hasil simulasi VecTor2 dengan menggunakan bond stress-slip effect akan dibandingkan dengan hasil pengujian eksperimen untuk melihat keakuratan simulasi VecTor2. Pada penelitian ini diperoleh nilai bond-slip 0,08 dan perbandingan nilai rasio untuk semua beban puncak antara 1,05 dan 1,06.
\end{abstract}

Kata kunci: balok beton bertulang, uji eksperimental, retak, pengaruh bond slip, simulasi VecTor2

\section{Pendahuluan}

Umumnya kegagalan struktur terjadi ketika struktur mendapat/memperoleh gaya yang menyerang struktur tersebut dan struktur tersebut tidak mampu mengatasi dan menahan beban/gaya yang terjadi pada struktur tersebut. Salah satu bagian struktur yang sering 
mengalami kegagalan/kerusakan saat terjadi gempa adalah balok (beam). Kegagalan ini umumnya terjadi akibat dari kurang memperhatikan detail desain penulangan dengan baik, baik untuk tulangan utama (tulangan horizontal) maupun tulangan sengkang (stirrups) pada balok beton bertulang, yang mengakibatkan balok tersebut mengalami kehancuran dan kerusakan (Sharma et al., 2011). Itulah sebabnya mengapa perencanaan balok/penulangan pada struktur bangunan haruslah dirancang dengan baik sesuai dengan standar dan aturan perencanaan bangunan desain beton bertulang. Struktur balok yang didesain/direncanakan nantinya harus mampu meminimalkan kerusakan dan kegagalan struktur.

Aspek lain yang perlu diperhatikan dalam perencanaan/desain struktur adalah perhitungan perpindahan (displacement) serta lendutan yang terjadi pada balok, sehingga ketika struktur memperoleh serangan gaya horizontal dan vertikal, bangunan dapat menahan gaya tersebut dan mencegah kerusakan dan kegagalan yang terjadi pada struktur bangunan tersebut dengan menggunakan penulangan yang baik dan benar. Untuk menyelidiki perilaku (kekuatan dan kegagalan) yang terjadi pada balok (beam) yang direncanakan/ desain maka perlu dilakukan simulasi dan pengujian terhadap balok tersebut. Untuk itu penggunaan software sangatlah penting dalam analisa maupun perencanaan saat ini. Program VecTor2/simulasi VecTor2 merupakan salah satu software analisis finite element yang terperinci dengan akurasi yang cukup untuk axial load, gaya geser, retakan, dan deformasi yang bisa digunakan dalam memprediksi setiap perilaku balok beton bertulang pada daerah/wilayah kritis di masa sekarang maupun masa yang akan datang.

Vector2 merupakan salah satu program analisis struktur elemen hingga (finite element) yang bisa digunakan dalam memprediksi setiap perilaku struktur balok (beam) terhadap gaya geser, axial load, perpindahan, dan kegagalan (retakan), (Walstra et al., 2013). Dalam penelitian ini, program elemen hingga nonlinear (VecTor2) digunakan untuk pemodelan 2 buah balok beton bertulang dari hasil pengujian laboratorium yang telah dilakukan Shim dan Vecchio pada tahun 2004. Balok beton bertulang yang dimodelkan dengan 2D nantinya dapat memperlihatkan lebih detail setiap perilaku dari tulangan yang digunakan baik untuk tulangan longitudinal maupun tulangan sengkang/begel (hoops) dan keruntuhan yang terjadi pada balok beton yang digunakan, itulah sebabnya hasil dari experiment test dan simulasi VecTor2 akan dibandingkan untuk dapat memperlihatkan setiap perilaku kegagalan dan kekuatan balok yang dianalisa. Hal ini juga dapat kita lihat dari hasil simulasi VecTor2 pada interior beam-column joint dimana setiap perilaku struktur yang terjadi pada sambungan balok-kolom dapat diprediksi dengan baik (Tampubolon et al., 2020).

\section{Metodologi}

VecTor2 adalah program analisis elemen hingga nonlinier (NLFEA) untuk analisis struktur membran beton bertulang dua dimensi. Jala halus elemen bertenaga rendah yang dibangun oleh model elemen hingga untuk VecTor2 dan metodologi ini memiliki keunggulan efisiensi komputasi, stabilitas numerik, dan cocok untuk struktur beton bertulang, yang membutuhkan jala yang relatif halus untuk memodelkan detail perkuatan dan pola retak lokal (Frank J Vecchio et al., 2013).

Pengujian balok beton bertulang telah di uji oleh Shim dan Vecchio pada tahun 2004 di University of Toronto. Tes percobaan balok beton bertulang untuk dua belas spesimen di lakukan dengan ukuran dan parameter yang berbeda untuk menunjukkan perilaku setiap balok beton bertulang saat diberikan beban. Perilaku untuk semua spesimen berbeda tergantung pada sifat material untuk beton, tulangan, dan panjang balok. Semua uji balok menggunakan penampang persegi panjang dengan kedalaman balok $552 \mathrm{~mm}$. Simulasi ini bertujuan untuk melihat perilaku balok seperti deformasi, beban maksimum yang dapat di terima/topang balok, dan pola retak yang terjadi. (F. J. Vecchio \& Shim, 2004)

Perilaku beton bertulang untuk retak, gaya geser, deformasi, tegangan, dan regangan dapat kita lihat dalam program analisis VecTor2 (Wong et al., 2013b). Perilaku ini sangat penting untuk diketahui terutama untuk balok (beam), sambungan balok kolom (beam-column joint), 
column (column) untuk mengetahui keamanan bangunan sebelum dilakukan pembangunan dilapangan. Sehingga, VecTor2 dapat digunakan di dalam memprediksi setiap kekuatan dan kegagalan struktur yang telah dilakukan pengujian eksperimen di laboratorium. Selain itu analisis VecTor2 dapat juga kita lihat pada perilaku interior beam-column joint untuk memprediksi gaya maksimum, perpindahan, dan pola retak yang terjadi.

Fokus utama dari penelitian ini adalah untuk memahami perilaku pengujian experiment test dari 2 buah balok beton bertulang dan kemampuan pemodelan VecTor2 dalam memprediksi kekuatan struktur di bawah pembebanan monotonik dan juga kondisi kontrol pemuatan pemindahan untuk struktur sesuai dengan pengujian experiment yang dilakukan di laboratorium tanpa mengubah setiap parameter yang digunakan. Oleh karena itu, berbagai jenis koneksi, sifat material, dan detail koneksi yang diperiksa sangat penting untuk mengkonfirmasi penerapan program atau mengidentifikasi. Perbedaan antara balok A1 dan A2 terdapat pada panjang balok, dimana untuk balok A1 menggunakan panjang bentang 3660 $\mathrm{mm}$ dan untuk balok A2 menggunakan panjang bentang $4570 \mathrm{~mm}$. Upaya pemodelan digunakan dengan menggunakan perilaku default atau opsi model konstitutif untuk membuktikan bahwa program berhasil menangkap parameter respons yang diperlukan tanpa modifikasi pada detail struktur.

Studi tentang perilaku bahan ikatan pada antar muka antara tulangan dan beton (bonds stressslip effect) merupakan salah satu bagian dari penelitian ini. Penelitian ini merumuskan bagaimana menghitung gaya geser, perpindahan, dan prediksi retak yang terjadi pada balok beton bertulang saat diberikan beban dan kontrol pemuatan perpindahan. Untuk mengetahui perilaku struktur, penting untuk memprediksi beberapa kegagalan dan kekuatan dari pada struktur atau elemen strukturnya. Tujuan dari penelitian ini adalah untuk menunjukkan keberhasilan menggunakan program untuk spesimen pemodelan konstitutif bahan baku. Hasil dari penelitian ini akan memungkinkan VecTor2 digunakan sebagai alat pemodelan untuk mengetahui perilaku beton bertulang dan akan memberikan data yang berguna untuk perencanaan struktur. Dengan demikian di masa akan datang, program VecTor2 akan digunakan untuk mendesain beberapa perilaku balok beton bertulang karena lebih mudah dan tidak mahal jika dibandingkan dengan studi eksperimental yang dilakukan di laboratorium. Selain itu, hasil dari simulasi VecTor2 juga dapat memberikan struktur data penilaian baik sebelum maupun sesudah struktur dikerjakan di lapangan.

\section{Beton}

Biasanya pengujian untuk beton dilakukan pada spesimen silinder dan spesimen kubus. Kekuatan tekan diperoleh dari pengujian di laboratorium dan spesimen lembab pada suhu $70^{\circ} \mathrm{F}$ dan umumnya umur beton yang digunakan adalah 28 hari. Kekuatan tekan dikenal sebagai kekuatan silinder $\left(\begin{array}{ll}f^{\prime} & c\end{array}\right)$ dan merupakan properti utama yang digunakan untuk tujuan desain. $\varepsilon \mathrm{c}$ 'adalah regangan tekan puncak beton yang tidak retak. Untuk beton normal, modulus elastisitas beton (Ec) dapat dihitung dengan (Mo, 2002):

$$
\mathrm{E}_{\mathrm{c}}=4730 \sqrt{\mathrm{fc}^{\mathrm{c}}} \mathrm{N} / \mathrm{mm}^{2}
$$

Tegangan tekan puncak beton retak, fp adalah:

$$
f_{p}=\beta . f_{c}{ }^{\prime}
$$

Terjadi pada tegangan puncak:

$$
\varepsilon_{\mathrm{p}}=\beta . \varepsilon_{\mathrm{c}}{ }^{\prime}
$$

Untuk menentukan kekuatan retak beton dan regangan retak dihitung dengan mengasumsikan hubungan linear-elastis sebelum retak dihitung dengan:

$$
\varepsilon_{\mathrm{cr}}=\frac{\mathrm{f}_{\mathrm{cr}}}{\mathrm{E}_{\mathrm{c}}}
$$


Ec adalah kekakuan tangen awal beton. Nilai fcr dan $\varepsilon c r$ kemudian digunakan dalam respon tegangan-regangan dan model-model pengerasan tegangan. Kekuatan Tarik beton ( $\left.\mathrm{f}^{\prime} \mathrm{t}\right)$ diambil sebagai kekuatan retak beton uniaksial tertentu dengan:

$$
\mathrm{f}^{\prime}{ }_{\mathrm{t}}=\beta \cdot \sqrt{\mathrm{f}_{\mathrm{c}}}
$$

Regangan silinder pada f'c, regangan tekanan $\left({ }^{\varepsilon_{0}}\right)$, sesuai dengan f'c, sebagai nilai positif dalam millistrain dihitung dengan:

$$
\varepsilon_{0}=1.8+0.0075 \mathrm{f}_{\mathrm{c}}
$$

Untuk analisis VecTor2, material beton sangat penting dan harus mendapatkan data yang jelas sesuai dengan pengujian laboratorium. Perilaku analisis lebih jelas ketika penggunaan data sesuai dengan pengujian. Tabel 1 memberikan parameter beton yang digunakan untuk analisis balok beton bertulang. Beberapa parameter akan diperoleh dari tes percobaan dan parameter lainnya dapat dihitung (Wong et al., 2013b).

\begin{tabular}{|c|c|c|}
\hline Defenisi & Simbol & Unit \\
\hline Cylinder compressive strength & $f_{c}^{\prime}$ & $M P a$ \\
\hline Tensile strength & $f_{t}^{\prime}$ & $M P a$ \\
\hline Initial tangent elastic modulus & $\mathrm{E}_{\mathrm{c}}$ & $M P a$ \\
\hline Cylinder strain at & $\mathrm{f}_{\mathrm{c}}^{\prime}, e O$ & $m e$ \\
\hline Poisson's ratio & $M u$ & - \\
\hline Thermal expansion coefficient & $C_{c}$ & $1{ }^{\circ} \mathrm{C}$ \\
\hline Maximum aggregate size & - & $m m$ \\
\hline Density & - & $K g / m^{3}$ \\
\hline Thermal diffusivity & $K_{c}$ & $\mathrm{Mm}^{2} / \mathrm{s}$ \\
\hline
\end{tabular}

Tabel 1. Material properties of concrete untuk simulasi VecTor 2

\section{Besi Beton / Tulangan}

Besi Tulangan digolongkan sebagai besi polos dan ulir. Secara umum, diameter batang polos adalah $6,8,10,12,14,16,18,20$ dan $22 \mathrm{~mm}$, sedangkan diameter besi ulir adalah $6,8,10$, $12,13,14,16,18,18,20,22,25,29,32,36,43$ dan $57 \mathrm{~mm}$. Klasifikasi tulangan baja dengan diameter kecil dan besar ditunjukkan pada Tabel 2 .

\begin{tabular}{|c|c|c|c|c|}
\hline ASTM & \multirow[b]{2}{*}{ Ukuran } & \multirow[b]{2}{*}{$\begin{array}{c}\text { Berat per meter } \\
(\mathbf{k g} / \mathbf{m})\end{array}$} & \multirow[b]{2}{*}{$\begin{array}{c}\text { Diameter Tulangan } \\
(\mathrm{mm})\end{array}$} & \multirow[b]{2}{*}{$\begin{array}{c}\text { Luas Tulangar } \\
\left(\mathrm{mm}^{2}\right)\end{array}$} \\
\hline $\begin{array}{l}\text { "Imperial" } \\
\text { Bar Size }\end{array}$ & & & & \\
\hline$\# 2$ & 6 & 0,249 & 6,3 & 32,000 \\
\hline$\# 3$ & 10 & 0,561 & 9,525 & 71,968 \\
\hline$\# 4$ & 13 & 0,996 & 12,700 & 129,032 \\
\hline$\# 5$ & 16 & 1,556 & 15,875 & 200,000 \\
\hline$\# 6$ & 19 & 2,240 & 19,050 & 283,870 \\
\hline$\# 7$ & 22 & 3,049 & 22,225 & 387,096 \\
\hline$\# 8$ & 25 & 3,982 & 25,400 & 509,676 \\
\hline \#9 & 29 & 5,071 & 28,651 & 645,160 \\
\hline$\# 10$ & 32 & 6,418 & 32,258 & 819,353 \\
\hline \# 11 & 36 & 7,924 & 35,814 & 1006,450 \\
\hline$\# 14$ & 43 & 11,410 & 43,002 & 1451,610 \\
\hline \# 18 & 57 & 20,284 & 57,328 & 2580,640 \\
\hline
\end{tabular}

Tabel 2. ASTM ukuran/ dimensi tulangan

Detail parameter tulangan baja untuk analisis VecTor2 ditunjukkan pada Tabel 3 (Wong et al., 2013a). Parameter ini digunakan untuk memodelkan analisis balok beton bertulang. 
JURNAL REKAYASA KONSTRUKSI MEKANIKA SIPIL (JRKMS)

Vol. 03 No. 02 September 2020 p-ISSN 2614-5707 e-ISSN 2715-1581

Tabel 3. Material properties tulangan beton untuk simulasi VecTor2

\begin{tabular}{|l|c|c|}
\hline \multicolumn{1}{|c|}{ Defenisi } & Simbol & Unit \\
\hline Reinforcement ratio & $\mathrm{rho}$ & $\%$ \\
\hline Reinforcement diameter & $\mathrm{d}_{\mathrm{b}}$ & $\mathrm{mm}$ \\
\hline Cross sectional area & $\mathrm{A}$ & $\mathrm{mm}^{2}$ \\
\hline Yield strength & $\mathrm{f}_{\mathrm{v}}$ & $\mathrm{MPa}$ \\
\hline Ultimate strength & $f_{u}$ & $\mathrm{MPa}$ \\
\hline Elastic modulus & $E_{s}$ & $\mathrm{MPa}$ \\
\hline Strain hardening strain & $e s h$ & $\mathrm{me}$ \\
\hline Ultimate strain & $e u$ & $m e$ \\
\hline Thermal expansion coefficient & $C_{s}$ & $/{ }^{\circ} \mathrm{C}$ \\
\hline
\end{tabular}

\section{Bond Stress- Slip}

Menurut kode CEB (1993), sebagian besar didasarkan pada model Eligehausen, Popov, dan Bertero (1983), parameter untuk beton terbatas berlaku setiap kali tekanan melintang $p \geq 7,5$ $\mathrm{MPa}$ atau penguat melintang yang berjarak dekat (Sagbas, G 2007). Tekanan kurungan nol sesuai dengan kasus kegagalan pemisahan yang tidak terbatas, sementara tekanan kurungan 7,5 $\mathrm{MPa}$ sesuai dengan kasus kegagalan penarikan yang terbatas. Gambar 1 menunjukkan posisi rasio tulangan melintang untuk setiap jumlah lapisan palang posisi. Berdasarkan tekanan kurung yang diantisipasi, $\sigma$, faktor tekanan kurungan dapat dihitung sebagai berikut:

$\beta=\frac{\sigma}{7.5}$

(in Mpa) $0 \mathbb{C} \beta \mathbb{C} 1$

$\sigma=\rho_{t} \cdot f_{y}$

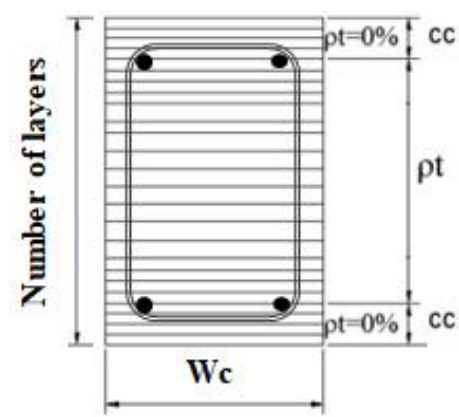

Gambar 1. Transverse reinforcement ratio position

\section{Hasil dan Pembahasan}

Dari hasil eksperimen test yang telah dilakukan maka diperoleh beberapa data yang digunakan untuk pengujian balok beton bertulang pada simulasi VecTor2 diantaranya:

\section{Penulangan Beton Bertulang (steel reinforcement concrete)}

Tulangan utama baja untuk pengujian eksperimen menggunakan ukuran palang M10, M25, dan M30, untuk sengkang menggunakan ukuran tulangan D-5. Untuk analisis ini nilai yield strength bar dan tensile strength bar memberikan pengaruh yang besar terhadap analisis perilaku balok, karena pada saat kita mendapatkan nilai kuat luluh dan kuat tarik tinggi otomatis nilai gaya gesernya akan tinggi, tetapi jika semakin kecil nilai gaya geser semakin kecil. Perilaku ini menunjukkan pengaruh batang luluh dan batang tarik memberikan pengaruh yang besar terhadap kekuatan balok saat melakukan uji eksperimen maupun uji simulasi. Untuk mengetahui jelas tulangan baja untuk pengujian ini, Tabel 4 menunjukkan detail dan parameternya. Untuk benda uji, A1 dan A2 memiliki kekuatan leleh yang sama dari baja sengkang namun untuk jumlah tulangan utama berbeda untuk kedua benda uji ini. Sementara itu, material beton yang digunakan pada uji eksperimen ini dapat di lihat pada Tabel 5, dimana nilai mutu beton untuk balok A1 dan A2 berbeda. Gambar 2 menunjukkan detail balok elevasi dan balok penampang A1 dan A2 untuk pengujian. 
JURNAL REKAYASA KONSTRUKSI MEKANIKA SIPIL (JRKMS)

Tabel 4. Detail dan parameter tulangan spesimen A1 and A2

\begin{tabular}{|c|c|c|c|c|c|c|c|}
\hline \multirow{2}{*}{ Tipe } & $\begin{array}{c}\text { Reinforcement } \\
\text { Properties }\end{array}$ & $\begin{array}{c}\mathbf{d b} \\
\mathbf{( m m )}\end{array}$ & $\begin{array}{c}\mathbf{A b} \\
\left(\mathbf{m m}^{\mathbf{2}}\right)\end{array}$ & $\begin{array}{c}\mathbf{E s} \\
\mathbf{( M P a})\end{array}$ & $\begin{array}{c}\mathbf{f y} \\
\mathbf{( M P a )}\end{array}$ & $\begin{array}{c}\boldsymbol{\varepsilon}_{\mathbf{u}} \\
(\mathbf{x 1 0}\end{array}$ & $\begin{array}{c}\text { fu } \\
(\mathbf{M P a})\end{array}$ \\
\hline \multirow{3}{*}{ A1 and A2 } & $\mathrm{M} 10$ & 11,3 & 100 & 200000 & 315 & 10 & 460 \\
& $\mathrm{M} 25$ & 25,2 & 500 & 220000 & 445 & 10 & 680 \\
& $\mathrm{M} 30$ & 29,9 & 700 & 200000 & 436 & 10 & 700 \\
\cline { 2 - 8 } & $\mathrm{D} 5$ & 6,4 & 32.2 & 200000 & 600 & 10 & 649 \\
\hline
\end{tabular}

Tabel 5. Detail dan parameter beton (concrete) spesimen A1 and A2

\begin{tabular}{|c|c|c|c|c|c|c|}
\hline Specimen & Ec (MPa) & f'c (MPa) & $\begin{array}{c}\mathbf{f}_{\text {sp }} \\
(\mathbf{M P a})\end{array}$ & $\mathbf{f ' t ~ ( M P a )}$ & $\begin{array}{c}\text { Aggregate Size } \\
(\mathbf{m m})\end{array}$ & $\begin{array}{c}\boldsymbol{\varepsilon} 0 \\
\left(\mathbf{x 1 0}^{\mathbf{3}}\right)\end{array}$ \\
\hline $\mathrm{A} 1$ & 36500 & 22,6 & 2,37 & 1.568 & 20 & 16 \\
\hline $\mathrm{A} 2$ & 32900 & 25,9 & 3,37 & 1.679 & 20 & 21 \\
\hline
\end{tabular}

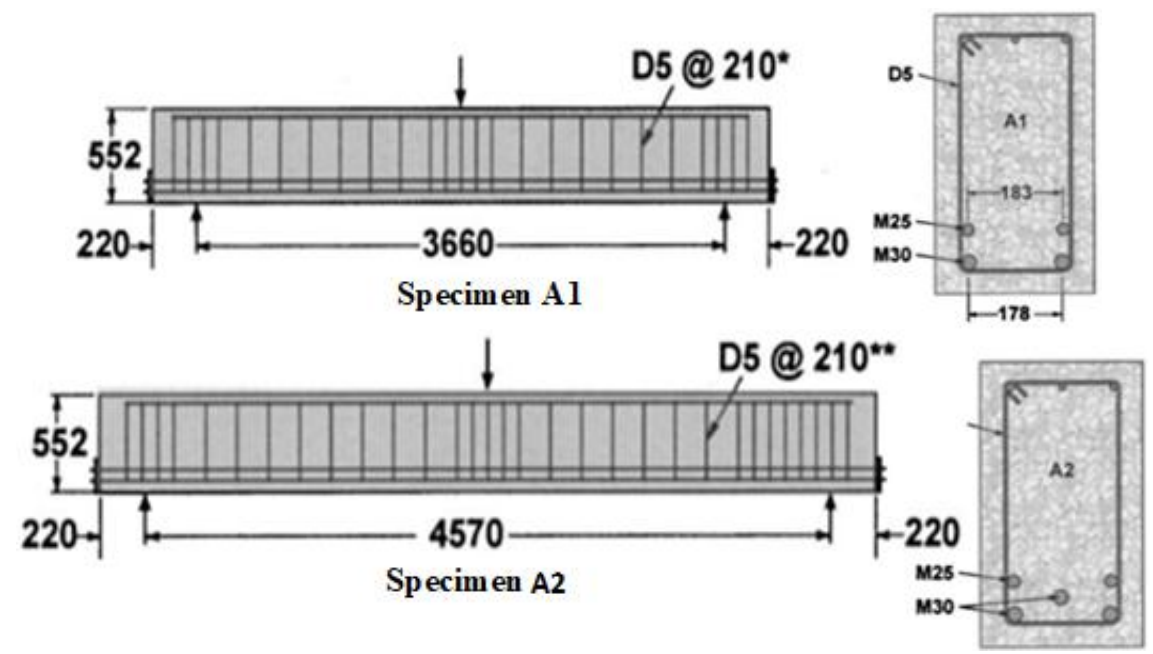

Gambar 2. Elevation detail and cross section details of Toronto beams (Shim and Vecchio, 2004)

Perbedaan antara balok A1 dan A2 terdapat pada panjang balok, dimana balok A1 menggunakan panjang bentang $3660 \mathrm{~mm}$ dan untuk balok A2 menggunakan panjang bentang $4570 \mathrm{~mm}$. Nilai kuat tekan beton dan modulus elastisitas beton yang digunakan juga berbeda untuk spesimen A1 dan A2. Kontrol pembebanan diterapkan pada bentang tengah untuk menunjukkan defleksi dan beban aksial.

\section{Set-up pengujian balok beton bertulang dan simulasi VecTor2}

Set-up pengujian untuk percobaan pengujian spesimen A1 dan A2 ditunjukkan pada Gambar 3. Lendutan beban diterapkan pada bentang tengah untuk mengetahui perilaku balok. Pembebanan akan dilakukan sampai balok mampu menahan beban yang diberikan. Lendutan pembebanan akan memberikan retakan pada pengujian balok dan memberikan beban yang maksimal yang dapat di terima balok (F. J. Vecchio \& Shim, 2004).

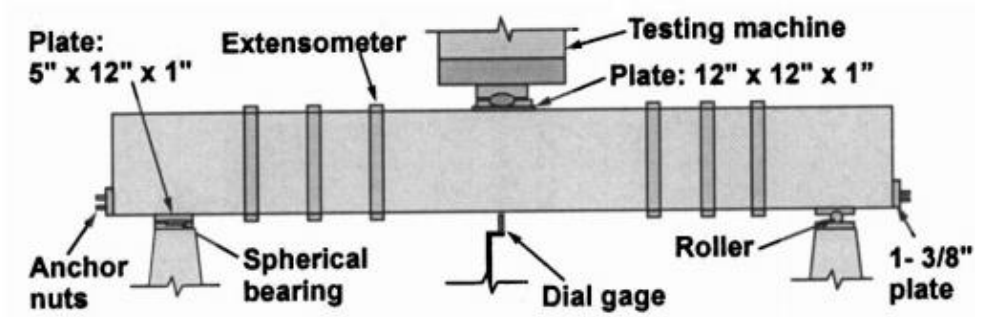

Gambar 3. Pengaturan eksperimen test untuk balok A1 dan A2, Toronto (Shim dan Vecchio, 2004) 
JURNAL REKAYASA KONSTRUKSI MEKANIKA SIPIL (JRKMS)

Untuk pemodelan Vector2 hanya mengambil setengah dari panjang bentang balok uji. Perilaku yang sama dengan pengujian eksperimen, defleksi beban untuk analisis VecTor2 diterapkan pada bentang tengah balok. Kondisi batas untuk penampang balok simulasi A1 dan A2 diterapkan slider (vertikal) di tengah balok dan di sisi kiri balok dipasang roller. Gambar 4 menunjukkan pemodelan balok A1 dan A2 untuk simulasi VecTor2 dimana pada pemodelan ini terlebih dahulu ditentukan wilayah (region) untuk ukuran balok yang digunakan sesuai dengan pengujian laboratorium, ukuran elemen (mesh), dan material yang digunakan di input pada simulasi VecTor2.

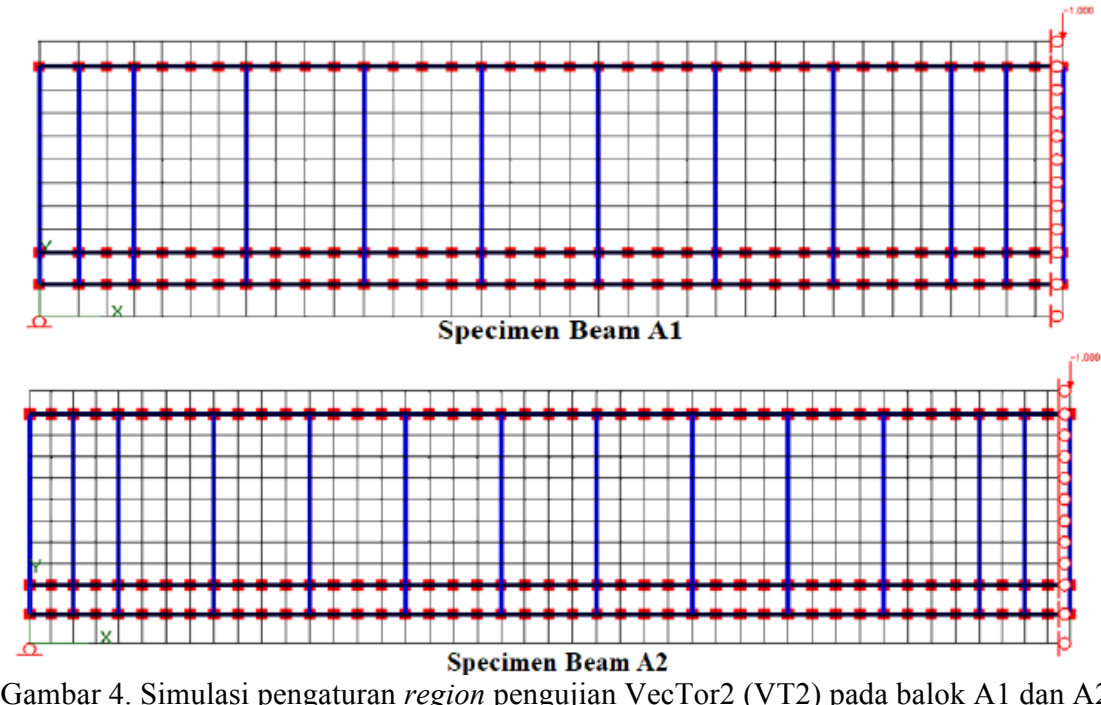

\section{Perhitungan bond-slip}

Pada penelitian ini akan dilakukan perhitungan nilai dari bond-slip pada balok beton bertulang tipe A1 dan A2. Berikut ini merupakan analisa perhitungan untuk mendapatkan nilai bond-slip.
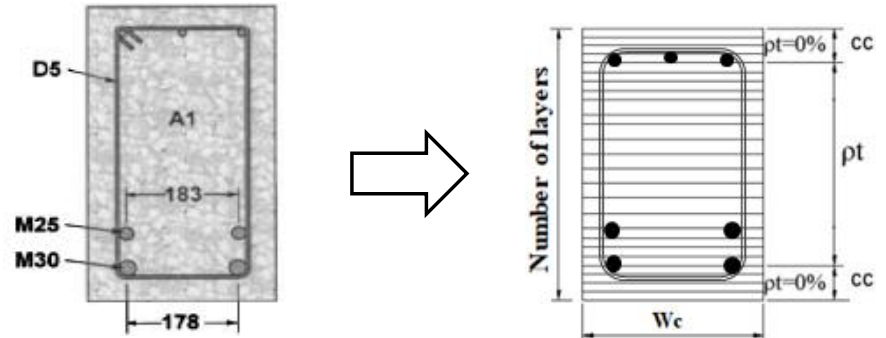

Gambar 5. Detail rasio dan tulangan melintang balok A1 dan A2

$\rho t=\frac{2 \times A b}{\text { stxwc }}=\frac{2 \times 32.2}{210 \times 305}=1.005 \times 10^{-3}=0.1 \%$

$\beta=\frac{\sigma}{7.5}$; (in MPa) $0 \leq \beta \leq 1$

$\sigma=\rho_{\mathrm{t}} \times \mathrm{f}_{y}=0.001 \times 600=0.6 \mathrm{MPa}$

$\beta=\frac{\sigma}{7.5}=\frac{0.6}{7.5}=0.08$

\section{Simulasi balok beton bertulang dengan menggunakan VecTor2}

Simulasi balok VecTor2 memberikan beberapa perilaku yang berbeda untuk kedua spesimen ini ketika diterapkan tekanan kurungan bond-slip. Sebelum menghitung nilai tekanan kurungan, diperoleh nilai bond-slip out of try and error. Nilai try and error untuk balok A1 diperoleh 0,06 dan 0,07 untuk balok A2, pada perhitungan bond-slip diperoleh nilainya 0,08. 
JURNAL REKAYASA KONSTRUKSI MEKANIKA SIPIL (JRKMS)

Ukuran elemen yang digunakan dalam analisa ini adalah (50 x 50) mm. Jumlah nodal balok A1 sebanyak 540 nodal dan jumlah elemen sebanyak 598 elemen, sedangkan untuk balok A2 jumlah nodal sebanyak 675 nodal dan jumlah elemen sebanyak 742 elemen. Pada dasarnya, retakan pada balok terjadi seperti garis diagonal pada saat diterapkan beban defleksi pada bentang tengah balok beton bertulang.

Perilaku pengujian balok A1 dan A2 berbeda karena beberapa parameter seperti bentang panjang, jumlah tulangan utama, kuat tekan beton, dan modulus elastisitas beton. Untuk simulasi balok VecTor2 A1 didapatkan nilai beban puncak 487,4 $\mathrm{kN}$ dan uji eksperimen mendapatkan nilai $459 \mathrm{kN}$. Analisis rasio dan uji eksperimen untuk beban puncak adalah 1,06 , sedangkan untuk defleksi bentang tengah pada bentang tengah didapatkan nilai untuk simulasi VecTor2 24,9 mm dan untuk uji coba nilai lendutan $18,8 \mathrm{~mm}$. Jadi, nilai simulasi VecTor2 dan hasil pengujian laboratorium tidak jauh. Dari hasil simulasi yang kita peroleh dapat kita lihat bahwa simulasi VecTor2 dapat memprediksi setiap perilaku yang terjadi pada balok beton bertulang dengan nilai dari bond-slip nya sebesar 0,08, dan hal ini juga dipengaruhi oleh ukuran elemen yang digunakan. Semakin kecil elemen yang kita gunakan pada simulasi VecTor2, maka pola keruntuhan/ retak yang terjadi akan semakin terlihat jelas detailnya dan akan mempermudah kita dalam membandingkannya dengan hasil pengujian laboratorium. Tabel 6 menunjukkan hasil spesimen balok A1 untuk pengujian eksperimen dan simulasi VecTor2. Gambar 6 menunjukkan grafik perbandingan hasil eksperimen dan simulasi VecTor2 untuk beban-defleksi balok A1. Selanjutnya, perbandingan retak dari hasil pengujian eksperimen dan simulasi VecTor2 balok A1 ditunjukkan pada Gambar 7.

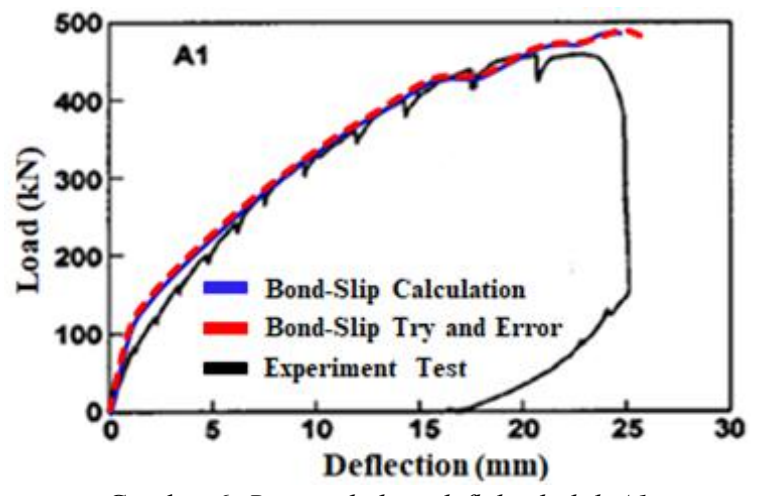

Gambar 6. Respon beban-defleksi balok A1

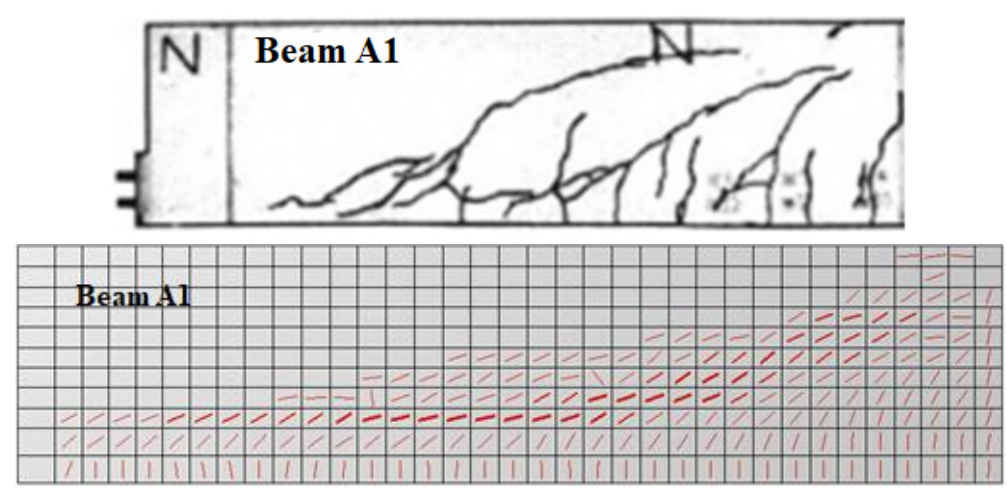

Gambar 7. Perbandingan hasil uji retak pada eksperimen test dan simulasi VecTor2 pada balok A1 
JURNAL REKAYASA KONSTRUKSI MEKANIKA SIPIL (JRKMS)

Vol. 03 No. 02 September 2020

p-ISSN 2614-5707 e-ISSN 2715-1581

Tabel 6. Perbandingan hasil eksperimen test dan simulasi VecTor2 pada balok A1

\begin{tabular}{|c|c|c|c|}
\hline Specimen $(\mathbf{A 1})$ & $\begin{array}{c}\text { Eksperimen } \\
(\mathbf{k N})\end{array}$ & $\begin{array}{c}\text { Simulasi } \\
\text { Vector2 }(\mathbf{k N})\end{array}$ & Ratio $=\frac{\text { VT2 }}{\text { Exprt }}$ \\
\hline Ultimate load capacity of beam $(\mathrm{Pu}), \mathrm{kN}$ & 459 & 487,4 & 1,06 \\
\hline Mid-span deflection at peak load $(\boldsymbol{\delta} \mathrm{u}), \mathrm{mm}$ & 18,80 & 24,9 & 1,32 \\
\hline Bond slip calculation & - & 0,08 & - \\
\hline Bond slip try and error & - & 0,06 & - \\
\hline Failure Mechanism & $\begin{array}{c}\text { Shear Compression } \\
(\mathrm{V}-\mathrm{C})\end{array}$ & $\begin{array}{c}\text { Shear Compression } \\
(\mathrm{V}-\mathrm{C})\end{array}$ & - \\
\hline
\end{tabular}

Untuk simulasi balok VecTor2 A2 didapatkan nilai beban puncak 458,61 kN dan uji eksperimen mendapatkan nilai $439 \mathrm{kN}$. Analisis rasio dan pengujian eksperimen untuk beban puncak adalah 1,05, sedangkan untuk defleksi bentang tengah pada bentang tengah mendapatkan nilai untuk simulasi VecTor2 $32,9 \mathrm{~mm}$ dan untuk eksperimen menguji nilai lendutan 29,1 mm. Jadi nilai simulasi VecTor2 dan uji coba tidak jauh. Tabel 7 menunjukkan hasil spesimen balok A2 untuk pengujian eksperimen dan simulasi VecTor2 dan Gambar 8 menunjukkan grafik untuk balok defleksi beban A2. Perilaku lain untuk melihat perbandingan retak dari percobaan dan simulasi VecTor2 balok A2 akan ditampilkan pada Gambar 9.

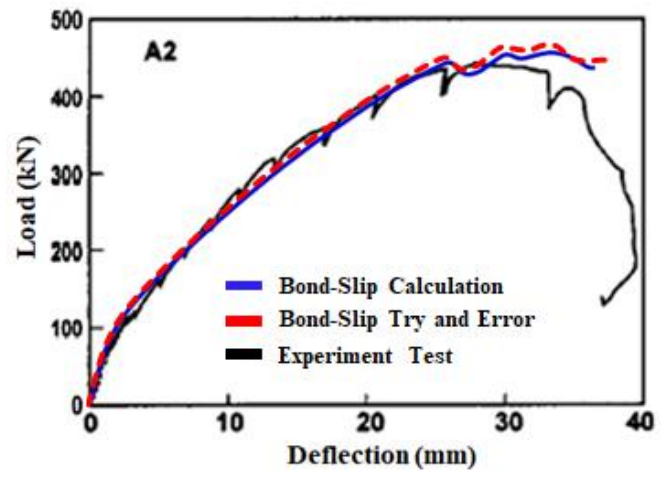

Gambar 8. Respon beban-defleksi balok A2

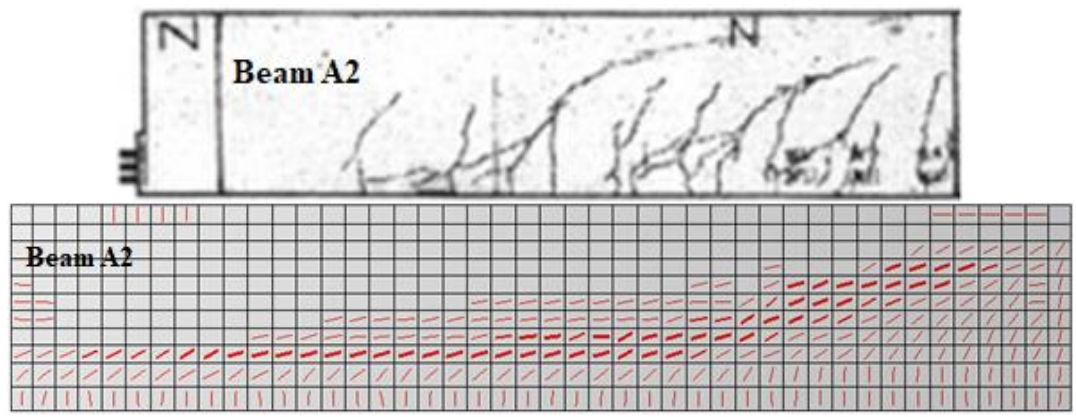

Gambar 9. Perbandingan hasil uji retak pada eksperimen test dan simulasi VecTor2 pada balok A2

Tabel 7. erbandingan hasil eksperimen test dan simulasi VecTor2 pada balok A2

\begin{tabular}{|c|c|c|c|}
\hline Specimen (A2) & $\begin{array}{c}\text { Eksperimen } \\
(\mathbf{k N})\end{array}$ & $\begin{array}{c}\text { Simulasi Vector2 } \\
(\mathbf{k N})\end{array}$ & Ratio= $\frac{\text { VT2 }}{\text { Exprt }}$ \\
\hline Ultimate load capacity of beam $(\mathrm{Pu}), k N$ & 439 & 458,61 & 1,05 \\
\hline Mid-span deflection at peak load $(\boldsymbol{\delta u}), \mathrm{mm}$ & 29,1 & 32,9 & 1,13 \\
\hline Bond slip calculation & - & 0.08 & - \\
\hline Bond slip try and error & - & 0.07 & - \\
\hline Failure Mechanism & $\begin{array}{c}\text { Shear Compression } \\
(\mathrm{V}-\mathrm{C})\end{array}$ & $\begin{array}{c}\text { Shear Compression } \\
(\mathrm{V}-\mathrm{C})\end{array}$ & - \\
\hline
\end{tabular}


Dari hasil simulasi VecTor2 dan pengujian eksperimen diperoleh nilai yang tidak jauh berbeda jika dilihat dari nilai perbandingan rasionya antara 1,05 dan 1,06 dengan nilai bondslip 0,08 untuk pengujian balok A1 dan A2 hal ini juga dapat dilihat dari pola retak yang terjadi pada setiap spesimen balok artinya simulasi VecTor2 dapat memprediksi setiap perilaku kegagalan yang terjasi pada balok beton bertulang. Disisi lain simulasi VecTor2 juga dapat kita lihat dalam pengujian interior beam-column joint dimana diperoleh nilai rasio perbandingan 0,98 dengan nilai bond-slip 0,186 dan simulasi VecTor2 dapat memprediksi setiap perilaku dan kegagalan yang terjadi pada sambungan balok-kolom (Tampubolon et al., 2020).

\section{Kesimpulan}

Pada pengujian balok beton bertulang dengan menggunakan simulasi VecTor2 pada balok tipe A1 dan tipe A2 memberikan beberapa kesimpulan di dalam memprediksi setiap perilaku balok beton bertulang dan dibandingkan dengan pengujian eksperimen test. Adapun kesimpulan yang dapat kita peroleh dari hasil penelitian ini diantaranya:

a. Simulasi VecTor2 dapat memprediksi setiap perilaku balok beton bertulang untuk melihat retak, perpindahan dan gaya geser maksimum.

b. Besarnya nilai gaya lateral tergantung dari kuat tarik tulangan dan kuat luluh tulangan, jika kuat tarik tulangan dan kuat luluh tulangan tinggi maka gaya lateral akan tinggi, begitu pula sebaliknya.

c. Nilai batang tertanam stress-slip bond tergantung dari rasio tulangan melintang dan tekanan pengekang tulangan.

d. Pada simulasi ini diperoleh nilai bond-slip 0,08 untuk balok tipe A1 dan A2.

e. Dari hasil simulasi VecTor2 didapatkan perbandingan nilai rasio untuk semua beban puncak antara 1,05 dan 1,06.

f. Dari hasil perhitungan dan simulasi didapatkan rata-rata ikatan tekanan kurungan slip untuk tulangan pasca luluh berkisar antara $0,005 \sqrt{ } \mathrm{fc}$ sampai $0,04 \sqrt{\mathrm{fc}}$.

\section{Referensi}

Mo, Y. L. (2002). Reinforced concrete structures. In Earthquake Engineering Handbook. https://doi.org/10.1201/b19154-3

Sharma, A., Eligehausen, R., \& Reddy, G. R. (2011). A new model to simulate joint shear behavior of poorly detailed beam-column connections in RC structures under seismic loads, Part I: Exterior joints. Engineering Structures. https://doi.org/10.1016/j.engstruct.2010.12.026

Tampubolon, S. P., Wang, C. Y., \& Wang, R. Z. (2020). Numerical simulations of the bond stress-slip effect of reinforced concrete on the push over behavior of interior beam-column joint. IOP Conference Series: Materials Science and Engineering. https://doi.org/10.1088/1757$899 \mathrm{X} / 725 / 1 / 012028$

Vecchio, F. J., \& Shim, W. (2004). Experimental and Analytical Reexamination of Classic Concrete Beam Tests. Journal of Structural Engineering, 130(3), 460-469. https://doi.org/10.1061/(ASCE)0733-9445(2004)130:3(460)

Vecchio, Frank J, Wong, P., \& Trommels, H. (2013). Vector2 \& Formworks User's Manual. In Second Edition. https://doi.org/10.1007/s007690000247

Walstra, P., Wouters, J. T. M., \& Geurts, T. J. (2013). VECTOR2 \& FORMWORKS USER'S MANUAL Second Edition Second Edition. Dairy Science \& Technology, CRC Taylor \& Francis Group.

Wong, P. S., Vecchio, F. J., \& Trommels, H. (2013a). VecTor2 \& Formworks User's Manual, Second Edition. In University of Toronto.

Wong, P. S., Vecchio, F. J., \& Trommels, H. (2013b). VecTor2 and Formworks user's manual. University of Toronto. 


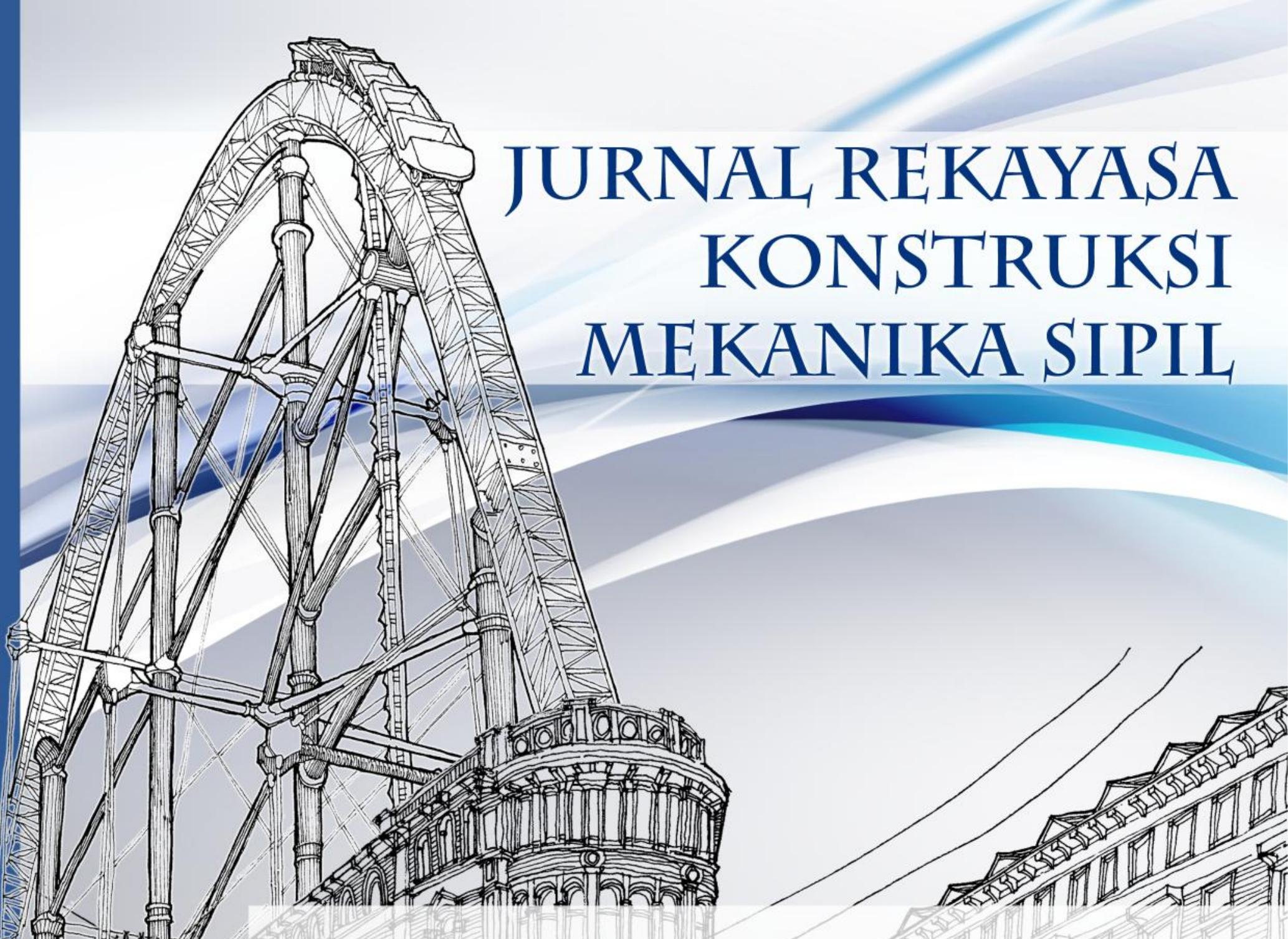

Analisa Perilaku Balok Beton Bertulang dengan Menggunakan Simulasi VecTor2

Sudarno P. TAMPUBOLON

Review Faktor - Faktor Yang Mempengaruhi Karakteristik Kuat Tekan Beton Geopolimer

Putrilyan Ezra PANJAITAN \& Liana HERLINA

Analisis Penerapan Metode Analytic Hierarchy Process (AHP) dalam Penentuan

Daerah Tangkapan Air di Sub DAS Cisadane Hulu

Dina Paramitha Anggraeni HIDAYAT

Dampak Pandemi Covid-19 Terhadap Tingkat Pelayanan Moda Transportasi

Speedboat Tidore-Sofifi

Abdul GAUS, Mufti Amir SULTAN, Iis Hamsir Ayub WAHAB, Abdul Majid ABDULLAH,

\& Nu'man NU'MAN

Analisis Proyeksi Jadwal Dan Biaya Akhir Dengan Konsep Nilai Hasil Pada Proyek Konstruksi

Silvia Yulita RATIH \& Dody IRNAWAN

Fakultas Teknik

Universitas Katolik Santo Thomas

JI. Setia Budi No. 479-F Tanjung Sari, Medan 


\section{Jurnal Rekayasa Konstruksi Mekanika Sipil (JRKMS)}

Jurnal Rekayasa Konstruksi Mekanika Sipil (JRKMS) diterbitkan oleh Fakultas Teknik Universitas Katolik Santo Thomas. JRKMS berisi artikel-artikel ilmiah yang meliputi kajian di bidang Teknik khususnya Teknik Sipil seperti Matematika teknik, Mekanika teknik, Analisis struktur, Konstruksi baja, Konstruksi beton, Konstruksi kayu, Konstruksi gelas, Mekanika tanah, Teknik Pondasi, Hidrologi, Hidrolika, Bangunan air, Manajemen konstruksi, Dinamika Struktur, Earthquake Engineering, Informatika, Ilmu Ukur Tanah, Struktur bangunan sipil, Rekayasa Jalan Raya, serta penelitian-penelitian lain yang terkait dengan bidang-bidang tersebut.

Terbit dalam 2 (dua) kali setahun yaitu pada bulan April dan September

Penasehat :

Prof. Dr. Drs. Sihol Situngkir, MBA. (Rektor UNIKA)

\section{Ketua Penyunting :}

Ir. Oloan Sitohang, M.T. (Universitas Katolik Santo Thomas)

Manajer Jurnal :

Reynaldo, S.T., M.Eng. (Universitas Katolik Santo Thomas)

\section{Anggota Penyunting :}

Medis Sejahtera Surbakti, S.T, M.T., Ph.D. (Universitas Sumatera Utara)

Dr. Janner Simarmata (Universitas Negri Medan)

Ir. Martius Ginting, M.T. (Universitas Katolik Santo Thomas)

Samsuardi Batubara, S.T., M.T. (Universitas Katolik Santo Thomas)

\section{Mitra Bestari :}

Dr.Eng. Aleksander Purba (Universitas Lampung, Indonesia)

Ir. Binsar Silitonga, M.T. (Universitas Katolik Santo Thomas, Indonesia)

Ir. Charles Sitindaon, M.T. (Universitas Katolik Santo Thomas, Indonesia)

Dr. Erica Elice Uy (De La Salle University, Philippines)

Dr. Harijanto Setiawan (Universitas Atma Jaya Yogyakarta, Indonesia)

Dr.Eng. Jeffry Swingly Frans Sumarauw (Universitas Sam Ratulangi, Indonesia)

Prof. Dr-Ing. Johannes Tarigan (Universitas Sumatera Utara, Indonesia)

Linda Prasetyorini (Universitas Brawijaya, Malang, Indonesia)

Dr.Eng. Mia Wimala (Universitas Katolik Parahyangan, Indonesia)

Dr.Eng. Minson Simatupang (Universitas Halu Oleo, Indonesia)

Dr. Mochamad Raditya Pradana (Keppel Marine and Deepwater Technology, Singapura)

Dr. Senot Sangadji (Universitas Sebelas Maret, Indonesia)

Ir. Simon Dertha, M.T. (Universitas Katolik Santo Thomas, Indonesia)

Dr. Thi Nguyên Cao (Tien Giang University, Viet Nam)

\section{Ilustrator Sampul:}

Yulianto, ST., M.Eng

\section{Penerbit \& Alamat Redaksi:}

Fakultas Teknik Universitas Katolik Santo Thomas

J1. Setiabudi No. 479-F Tanjung Sari, Medan 20132

Telp. (061) 8210161 Fax : (061) 8213269

email : unika.sipil@yahoo.com 


\section{Konten}

REKAYASA STRUKTUR

Analisa Perilaku Balok Beton Bertulang dengan Menggunakan Simulasi VecTor2

Sudarno P. TAMPUBOLON

Review Faktor - Faktor Yang Mempengaruhi Karakteristik Kuat Tekan Beton Geopolimer

Putrilyan Ezra PANJAITAN \& Liana HERLINA

TEKNIK SUMBER DAYA AIR

Analisis Penerapan Metode Analytic Hierarchy Process (AHP) dalam

Penentuan Daerah Tangkapan Air di Sub DAS Cisadane Hulu

Dina Paramitha Anggraeni HIDAYAT

REKAYASA TRANSPORTASI

Dampak Pandemi Covid-19 Terhadap Tingkat Pelayanan Moda

$89-96$

Transportasi Speedboat Tidore-Sofifi

Abdul GAUS, Mufti Amir SULTAN, Iis Hamsir Ayub WAHAB, Abdul Majid

ABDULLAH, \& Nu'man NU'MAN

MANAJEMEN KONSTRUKSI

Analisis Proyeksi Jadwal Dan Biaya Akhir Dengan Konsep Nilai Hasil Pada

Proyek Konstruksi

Silvia Yulita RATIH \& Dody IRNAWAN hal.

55-64

65-79

9




\section{Pengantar Redaksi}

Puji dan syukur kami sampaikan kepada Tuhan Yang Maha Esa karena atas rahmatNya kami dapat menyelesaikan penerbitan Jurnal Rekayasa Konstruksi Mekanika Sipil (JRKMS) Volume 3 Nomor 2, di bulan September tahun 2020 ini. Jurnal ini fokus pada beragam subbidang dalam Teknik Sipil, yakni Rekayasa Struktur, Rekayasa Geoteknik, Rekayasa Transportasi, Teknik Sumber Daya Air, dan Manajemen Konstruksi. Namun, tidak menutup kesempatan bagi subbidang lainnya yang berkaitan dengan bidang Teknik Sipil. Pada tahun ke-3 terbitnya, JRKMS telah menerima terakreditasi ARJUNA dengan peringkat Sinta S5.

Meski masih dalam kondisi pandemi COVID-19, penelitian tetap harus dijalankan dan produktivitas peneliti di Indonesia masih harus terus berkembang. Dalam edisi ini, terdapat 5 artikel yang terdiri atas dua (2) artikel dalam topik Rekayasa Struktur, satu (1) artikel dalam topik Teknik Sumber Daya Air, satu (1) artikel dalam topik Rekayasa Transportasi, dan satu (1) artikel dalam topik Manajemen Konstruksi. Redaksi/Tim editorial memiliki kerinduan agar semakin banyak peneliti yang menerbitkan karya berkualitasnya di JRKMS untuk mendukung pengembangan wawasan dalam dunia teknik sipil. Apresiasi kami berikan kepada penulis yang tulisannya diterbitkan pada Vol.03 No.02 September 2020 ini karena telah menginvestasikan waktu dalam menuangkan ide dan merespon masukan dari mitra bestari hingga karyanya siap untuk diterbitkan.

Sebagai penutup, yang menjadi harapan tim editorial adalah semoga jurnal ini dapat menjadi media ilmiah yang berguna bagi civitas akademika, dan perkembangan ilmu pengetahuan serta penelitian di bidang ilmu ketekniksipilan di Indonesia. Salam hangat. Salam sehat.

September 2020

Tim Editorial 
JURNAL REKAYASA KONSTRUKSI MEKANIKA SIPIL | Volume 03 | No. 02 | September 2020 | Jurnal IImiahTeknik Sipil Fakultas Teknik Universitas Katolik Santo Thomas ejournal.ust.ac.id/index.php/JRKMS

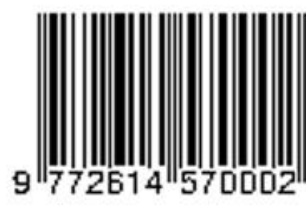

Google A GARUDA ISJDNeo : neliti Donesearch PBase 